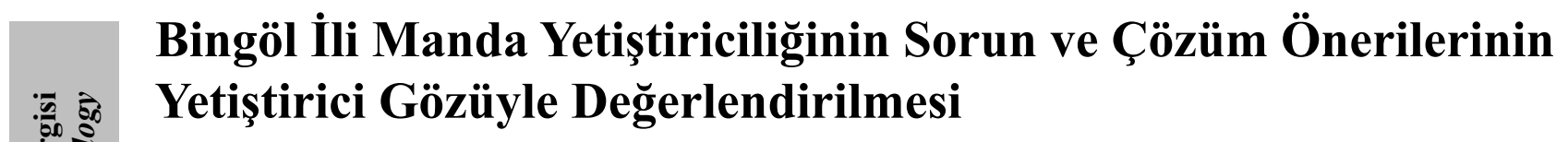

\author{
Gökçe ÖZDEMIR' ${ }^{1}$, Ayhan ÖZDEMIR²
}

ÖZET: Bu çalışma, Bingöl ili manda yetiştiriciliğinin yapısal ve teknik özelliklerini ortaya koymak, yetiştirici gözünde manda yetiştiriciliğinin sorunları, beklentileri ve çözüm önerileri ile yetiştiriciliğgin geleceğine yönelik düşüncelerini belirlemek amacıyla yapılmıştır. Araştırma materyalini, Bingöl ili merkez ilçeye bağlı manda yetiştiricilerinin ağırlıklı olarak bulunduğu 5 köyde toplam 51 işletme sahibi ile yüz yüze yapılan anketlerden elde edilen veriler oluşturmuş̧ur. Çalışmada elde edilen verilere göre, katılımcıların \%97.9'u manda yetiştiriciliğinden memnun olduğunu ve çocuklarına da manda yetiştiriciliğini tavsiye ettiklerini $(\% 80)$ ifade etmişlerdir. İşletme sahipleri, manda yetiştiriciliğinin sorunlarını "Yem fiyatı yüksek", "Para yok" ve "Hibe ve kredi desteği olmadığı" şeklinde sıralayarak, sorunlarının giderilmesi için yetkililerden çözüm beklemektedirler. En önemli beklentilerinin ise "Damızlık hayvan verilsin", "Ürünlerin pazarlama imkânları arttırılsın" ve "Kredi verilsin" şeklinde ifade etmişlerdir. "Manda yetiştiriciliği karlı hale getirilebilir mi?" sorusuna katılımcıların \%95.9'u evet cevabını vererek, çözüm önerisi olarak ise katılımcıların \%54.9'u pazar fiyatlarının artırılması, \%23.9'u yem ve damızlıkta kredi artırılması, \%15.9'u mera alanlarının arttırılması ve \%5.3'ü ise sürü genetiği iyileştirilmesi gerektiğini vurgulamışlardır.Sonuç olarak, katılımcıların tamamına yakınının manda yetiştiriciliğinden memnun olmaları, bu yetiştiriciliği çocuklarına tavsiye etmeleri, organik üretime gönüllü ve manda ürünlerin önemi ve kalitesinin farkında oldukları tespit edilmiştir. Bingöl ili özelinde manda yetiştiriciliğinin geliştirilebilmesi için yetiştiricilere organik yetiştiricilik imkanları kullanma yönünde teşvik edilmeleri ve pazar imkanlarının oluşturulması ile üretici açısından manda yetiştiricilerinin sorunlarına karşllık yetkilerden beklentileri ve çözüm önerilerini karşılayarak bir gelişme olacağ 1 düşünülmektedir.

Anahtar Kelimeler: Bingöl, çözüm önerisi, manda yetiştiriciliği, sorun

\section{The Assessment of Problems and Solution Suggestions towards Water Buffalo Breeding in Bingöl Province from the Perspective of Breeders}

\begin{abstract}
This study aims to reveal structural and technical features of water buffalo breeding in Bingöl province; to detect problems, expectations and solution suggestions on water buffalo breeding from the perspective of breeders and to determine breeders' views about the future of this kind of breeding. The research material consists of the data obtained from face-to-face surveys that were conducted with a total of 51 employers in 5 villages affiliated to the central district of Bingöl province where most water buffalo breeders reside. According to the data obtained in this study, $97.9 \%$ of participants reported that they are happy with water buffalo breeding and they suggest this activity to their children (80\%). Breeders ranged the problems related to water buffalo breeding as follows; "Feeding stuff costs are high", "I don't have any money" and "There is no grant and loan support"; they ranged their most important expectations from authorities to resolve their problems as follows; "They should provide breeding animal", "Marketing means of products should be improved" and "They should give loan". The question "Do you think water buffalo breeding can be made profitable?" was answered as "Yes" by $95.9 \%$ of participants while solution suggestions were emphasized as increasing market prices by $54.9 \%$; increasing loans for feeding stuff and breeding animals by $23.9 \%$; increasing pasture areas by $15.9 \%$ and improving flock genetics by $5.3 \%$. To conclude, it was found that almost all of the participants are pleased with water buffalo breeding, they suggest this breeding to their children, they are volunteer for organic production and they are aware of the importance and quality of water buffalo products. It is assumed that the creation of market opportunities and encouraging the use of organic aquaculture facilities should be organized to make breeders acquire knowledge and skills about water buffalo breeding in specific to Bingöl province.
\end{abstract}

Key words: Bingöl, problem, solution suggestion, water buffalo breeding

Bingöl Üniversitesi, Veteriner Fakültesi, Zootekni AD, Bingöl, Türkiye

Gıda Tarım ve Hayvancılık Bakanlığı, Bingöl İl Müdürlüğü, Bingöl, Türkiye

Sorumlu yazar/Corresponding Author: Gökçe ÖZDEMIR, gozdemir@bingol.edu.tr 


\section{GİRIŞ}

Manda, dünyada tamamına yakını Asya kıtasında bulunan (\%96.4), başta süt olmak üzere, et, deri ve iş gücünden yararlanmak amacıyla yetiştirilen Bovidae ailesinde bir türdür. Mandanın yetiştiricilikteki önemi, elde edilen süt ve et verimi ile hastalıklara kültür 1rkı sığırlara göre daha dayanıklı olması, kalitesiz kaba yemleri et ve süte dönüştürebilmesi, yetiștirme giderlerinin az olması gibi sebeplerle ekonomik düzeyi düşük yetiştiriciler için uygun bir çiftlik hayvanı olmasından kaynaklanmaktadır (İmik 2000; Küçükkebabçı ve Aslan 2002; Sarı̈zkan 2011; Alpan ve Aksoy 2012).

Türkiye'de 1980'lerde 1 milyon baş manda varlığından bahsedilirken, 2007 yılına gelindiğinde bu sayı 84.705 başa kadar düşmüştür. Manda popülasyonundaki bu önemli düzeydeki azalış; tarımdaki modernizasyona bağlı olarak, manda yetiştiriciliği için uygun arazilerin yok olması, entansif yetiştiriciliğe manda yetiştiricilerinin ayak uyduramaması, sı ğırlara oranla geç yaşlarda verim vermemeleri ile verimlerinin düşük olması, süt ve et ürünlerinin besinsel değerlerinin yeteri kadar tanıtılmaması ve manda yetiştiriciliğine devlet tarafından teşvik verilmemesi gibi sebeplerden kaynaklanmıştır. Gıda Tarım ve Hayvancılık Bakanlığ yaklaşımlar getirebilmek amacıyla özel teşvik ve destekleme programları oluşturulmuştur. Ayrıca Türkiye'de gen kaynaklarının korunmasına yönelik ulusal ve bölgesel projeler ile çeşitli illerde kurulan damızlık manda yetiştirici birlikleri üreticilere destek olmak suretiyle manda yetiştiriciliğinin geliştirilmesine katkıda bulunmaya çalışmaktadırlar (İmik 2000; Sarı̈̈zkan 2011; Kandır 2014b). Tüm bu çalışmalar ve desteklemeler ile birlikte 2014 yılında manda popülasyonu 121.826 başa ulaşmıştır (TÜİK 2015).

Bingöl ili manda varlığı ise 2009 yılında 63 baş iken, hayvancılık üretim kolları içerisinde manda yetiştiriciliğinin geliştirilmesi amacıyla gerek kamu gerekse birlikler ve üniversiteler kapsamında gerçekleştirilen çalışmalar sonucunda Türkiye genelindeki manda sayısındaki artışı Bingöl iline de yansımış ve 2014 yılı itibariyle manda sayısı 168 başa yükselmiştir (TÜİK 2015).

$\mathrm{Bu}$ çalışma, manda yetiştiriciliğinin ve ürünlerine önem kazandırılması amacıyla birçok kurumun çaba gösterdiği bu süreçte, Bingöl ili manda yetiştiriciliğinin yapısal ve teknik özelliklerini ortaya koymak, yetiştirici gözünde manda yetiştiriciliğinin sorunlarını, beklentilerini ve çözüm önerileri ile manda yetiştiriciliğinin geleceğine yönelik düşüncelerini belirlemek amacıyla gerçekleştirilmiştir.

\section{MATERYAL VE YÖNTEM}

Araştırma materyalini, Bingöl ili merkez ilçeye bağlı manda yetiştiricilerinin yoğun olarak bulunduğu 5 köyde toplam 51 işletme sahibi ile yüz yüze yapılan anketlerden elde edilen veriler oluşturmuştur. Bu çalışmada, manda yetiştiriciliğinin yapısal durumunun belirlenmesi amacıyla hazırlanmış olan anketin manda yetiştiricilerine ait yetiştiricilik sorunları ile yetiştiriciliği geliştirme olanakları ve çözüm önerileri gibi konularına ait soruları değerlendirilmiştir. Ayrıca çalışmada konu ile ilgili olarak daha önce yapılmış bilimsel çalışmalar ile kamu ve özel kuruluşların kayıtlarından da yararlanılmıştır. Anket çalışmaları, 2014 yılı Nisan-Mayıs ayları arasında gerçekleştirilmiştir.

Araştırma sonucu elde edilen verilerin değerlendirilmesinde tanımlayıcı istatistikler, frekanslar ve yüzde dağılım hesaplamaları kullanılmıştır. Verilerin değerlendirilmesinde SPSS paket programı kullanılmıştır.

\section{BULGULAR VE TARTIŞMA}

Manda yetiştiriciliğinin ve ürünlerinin organik değerinin farkındalık düzeyini belirleyebilmek amacıyla katılımcılara yöneltilen "Organik yetiştiricilik nedir, bilginiz var mı?" sorusuna katılımcıların \%82.4'ü hayır cevabını vermiş olmalarına rağmen, yetiştiricilere yöneltilen "Organik yetiştiricilik yapmak ister misiniz?" sorusuna ise $\% 81.6$ oranında evet cevabını vermişlerdir (Çizelge 1). Bingöl ilinde gerçekleştirilen birkaç çalışmada da (Çakmak ve 
ark. 2010; Özdemir ve ark. 2010), organik süt üretimi konusunda genel olarak üreticilerin bilgilerinin yetersiz olduğunu ve üreticilerin eğitim seviyesi ile organik süt elde etme düzeyleri arasında bir ilişkinin olduğu ortaya konulmuştur. Mandaların yetiştirilme şekilleri, hastalıklara karşı dirençlerinin yüksek olması, ilaç kullanma ve ürünlerine ilaç bulaşma riskini en aza indirdiğinden, elde edilen ürünlerin "organik" ve "sağlıklı" olduğunu söylemek mümkündür (Kandır 2014a). Ayrıca Türkiye'de bölgeler bazında, kirlenmemiş tarımsal alan yapısı, hava ve iklim koşullarıyla özellikle Doğu Anadolu bölgesinin organik süt üretimi için uygun bir potansiyeli sahiptir. Bingöl ili organik tarım ve organik hay- vanc1lı üretimi konusunda oldukça yüksek bir potansiyele sahiptir. Ancak bu tür çalışmaların başarılı olabilmesi yöre insanının çalışmaları benimsemesi ve yürütülmesi konusundaki yardımlarına bağlıdır (Çakmak ve ark. 2010; Özdemir ve ark. 2010; Anonim 2013).

Katılımcıların \%92.2 oranında bu işi süt üretimi amacıyla yaptıklarını bildirmişlerdir (Çizelge 1). Türkiye'de manda yetiştiriciliğinin sadece süt üretimi için köy şartlarında küçük aile işletmelerinde ve her işletmede 3-5 manda bulunduğunu bildirilmiştir (Şekerden ve ark. 2005; Borghese ve Mazzi, 2010; Akbulut ve Yazıcı 2011; Şahin ve ark. 2013).

Çizelge1. İşletmeler hakkında genel bilgiler

\begin{tabular}{|l|l|c|c|}
\hline \multirow{2}{*}{ Sorular } & \multirow{2}{*}{ Parametreler } & \multicolumn{2}{|c|}{ Bingöl İli Toplam } \\
\cline { 3 - 4 } & & $\mathbf{n}$ & $\mathbf{~}$ \\
\hline \multirow{2}{*}{$\begin{array}{l}\text { Organik yetiştiricilik } \\
\text { nedir, bilginiz var mı? }\end{array}$} & Evet & 9 & 17.6 \\
\cline { 2 - 4 } & Hayır & 42 & 82.4 \\
\hline \multirow{2}{*}{$\begin{array}{l}\text { Organik yetiştiricilik } \\
\text { yapmak ister misiniz? }\end{array}$} & Evet & 40 & 81.6 \\
\cline { 2 - 4 } & Hayır & 9 & 18.4 \\
\hline \multirow{2}{*}{$\begin{array}{l}\text { Manda yetiştiriciliğin de } \\
\text { amacınız }\end{array}$} & Besi (Et) & - & - \\
\cline { 2 - 4 } & Süt & 47 & 92.2 \\
\cline { 2 - 4 } & Karma (Et- Süt Kombine) & 4 & 7.8 \\
\hline
\end{tabular}

Katılımcıların işletmelerinde manda yetiştiriciliğ i dışında uğraştıkları üretimin, \%55'i büyükbaş hayvan yetiştiriciliği ile \%42'si ise bitkisel üretimdir (Şekil 1).

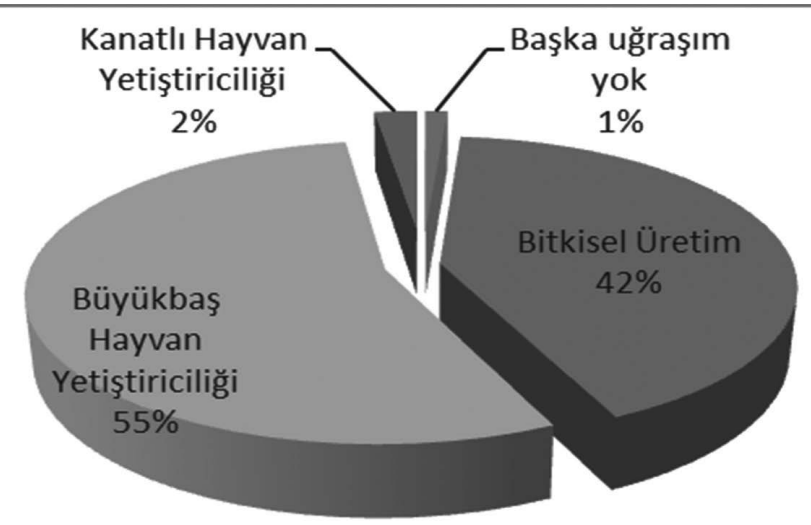

Soysal ve ark. 2005, tarafindan yürütülen bir çalışmada manda yetiştiricilerinin yarısının geçim kaynaklarının sadece hayvancılık olduğu belirlenmiştir.

Şekil 1. Manda yetiştiriciliği dışında uğraşılan iş sahaları

Katılımcılara yöneltilen "Neden manda yetiştiriciliği yapıyorsunuz?" sorusuna yetiştiriciler önem sırasına göre "Evimin günlük ihtiyacı için (Peynir, yoğurt, tereyağı)", "Aile mesleğimiz" ve "Coğrafik koşullar" cevaplarını vermişlerdir (Şekil 2). 


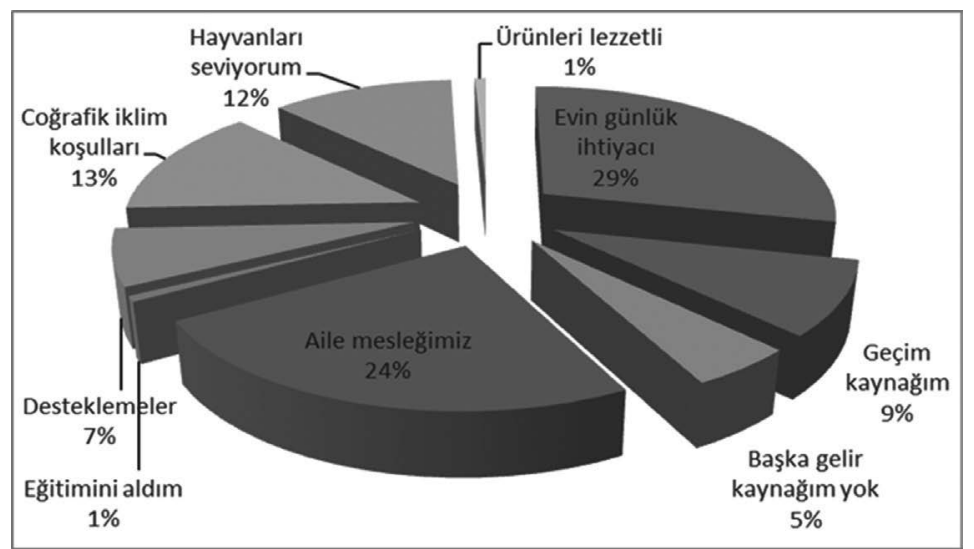

Şekil 2. Katılımcıların manda yetiştiriciliği yapma nedenleri

Katılımc1lara yöneltilen "Manda yetiştiriciliğinden memnun musunuz?" sorusuna $\% 97.9$ 'u evet, $\% 2.1$ 'i ise hayır cevabını verirken, $\% 80$ 'i çocuklarına manda yetiştiriciliğini tavsiye ettiklerini beyan etmişlerdir (Çizelge 2). Bir başka çalışmada yetiştiricilerin $\% 87.18$ oranında hayvancılıktan memnun olmadıkları tespit edilmiştir. Aynı çalışmada, yetiştiricilerin \%66.67'si ürettikleri ürünlerin fiyatlarının düşüklüğünü, \%16.67'si yapacak başka işi olmadığını, \%11.76'sı gelirin azlığını ve geri kalan \%4.90'ı ise pazarlama imkânlarının olmamasını gerekçe olarak sunduğu ve yeterli gelir elde edemeyen üreticilerin yaptıkları işten memnuniyet duymadıkları bildirilmiştir (Karadavut ve ark. 2010).

Çalışmaya katılan yetiştiriciler "Manda yetiştiriciliğini bıraksanız ne iş yaparsınız?" sorusuna çiftçilik (\%45), hayvancılık (\%22.5) sığır yetiştiriciliği veya besiciliği yaparım (\%17.5) yanttlarını verirken, katılımcıların \%12.5'i ise bu soruyu manda yetiştiriciliğini bırakmam şeklinde cevaplamışlardır (Çizelge 2). Manda yetiştiriciliğinin sorunlarının giderilmesi için yetkililerden en önemli beklentileri sorulan katılımcılar, beklentilerinin (\%33.3) "Damızlk hayvan verilsin", (\%15.7) "Ürünlerin pazarlama imkânları arttırılsın", (\%13.7) "Beklentim yok" ve (\%11.8) "Kredi verilsin" şeklinde ifade etmişlerdir (Çizelge 2). Farklı hayvancılık kollarında yürütülen bazı çalışmalarda da (Dellal ve ark. 2002; Özçelik ve Şahinli 2011; Şeker ve ark. 2012) yetiştiricilerin öncelikle yem fiyatları, kredi, veteriner hekimlik hizmetleri, damızlık hayvan temini, eğitim ve pazarlama konularında devletten beklenti içerisinde oldukları tespit edilmiştir. Bu bulgulardan hareketle manda yetiştiricilerinin hayvancılık ve yan kollarını oluşturan alanlarda çalışmayı devam ettirmeyi istediklerini ancak bu devamlılığın sağlanabilmesi adına teşvik ve destek beklentisi içerisinde oldukları söylenebilir.

Manda yetiştiricileri, işletmeleri için en önemli masraf kalemi olarak $\% 94.1$ oranında yem alımı olduğunu belirtmişlerdir (Çizelge 2). Katılımcıların en önemli masraf kalemi olarak yem alımını belirtmiş olması yanı sıra yetiştiricilikteki en önemli sorunları olarak yem fiyatlarının yüksek oluşunu ifade etmeleri, yem temininin yetiştiriciyi ekonomik açıdan zora soktuğunun bir diğer kanıtıdır. Şeker ve ark. 2012, Muş ilinde (\%48.7) ve Murat ve Sakarya 2012, Niğde ve Konya illerinde süt sığırcılık işletmelerde (\% 59.42) maliyeti oluşturan masraf unsurları arasinda yem/yem hammaddelerinin ilk sırayı aldığını bildirmişlerdir.

Yetiştiriciler "Manda yetiştiriciliğinin sorunları nelerdir?" sorusuna en önemli gördükleri üç seçeneği sırasıyla "Yem fiyatı yüksek", "Para yok" ve "Hibe ve kredi desteği olmadığından" şeklinde ifade etmişlerdir (Şekil 3). Mevcut çalışmanın bulguları; Bingöl ili hayvancılık işletmelerin genel olarak sorunları ve öncelik sıralamalarının, yetiştiricilerin ürettikleri ürünlerin düşük fiyatla satılması, yem fiyatlarının yüksekliği ve verimin düşüklüğü gibi üreticilerin karlılığını etkileyen birbirine bağlı değişkenler olduğu tespit edilen çalışma bulguları (Karadavut ve ark. 2010) ile paralellik göstermektedir. Katılımcilar, manda yetiştiriciliğinin sorunları, yetkililerden beklentileri ile çözüm önerilerini belirlemek adına sorulan sorulara verdikleri yanıtlar birlikte değerlendirildiğinde; temelde hayvancıllk sektörümüzün genel sorunları ve Türkiye'de manda say1sının azalışına sebep olarak literatürler de sıralanan temel faktörlerin karşımıza çıktığını görülmektedir (İmik 2000; Türkyılmaz ve Nazlıül 2002; Sarı̈̈zkan, 2011; Atasever ve ark. 2013). 


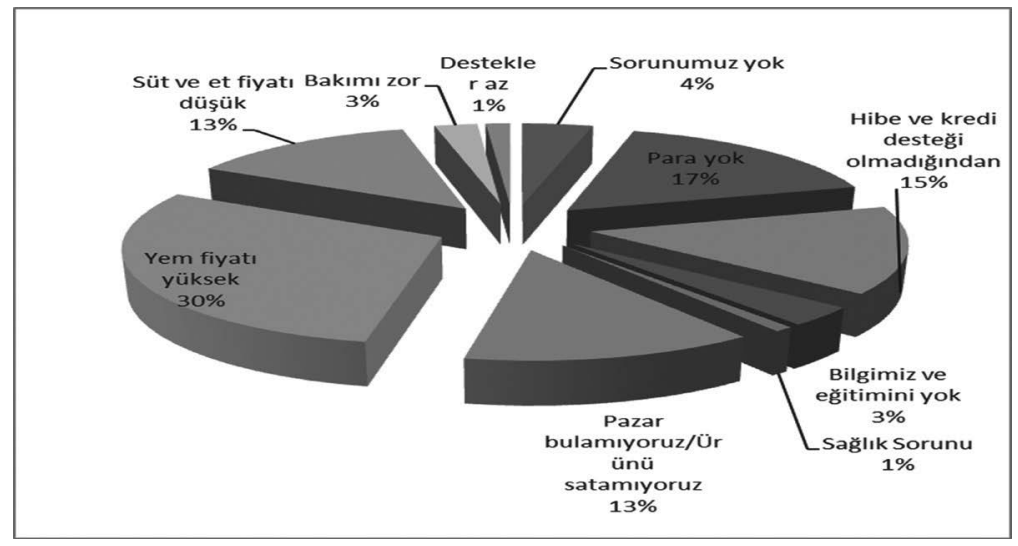

Şekil 3. Katılımcılara göre manda yetiştiriciliğinin sorunları

"Manda yetiștiriciliği karlı hale getirilebilir mi?" sorusuna katılımc1ların \%95.9'u evet cevab1nı vermişlerdir (Çizelge 2). Manda yetiştiriciliğin karlı hale getirilebilmesi için katılımcıları yaklaş1k \%54.9'u pazar fiyatlarının artırılması, \%23.9'u yem ve damılıkta kredi artırılması, \%15.9'u mera alanlarının arttırılması ve \%5.3'ü ise sürü genetiği iyileştirilmesi gerektiğini vurgulamışlardır (Şekil 4). Bu sonuçlar hayvancılığın yaşadığ 1 genel problemlere hem yetiştirici hem de bilirkişiler tarafından öne sürülen çözümler olarak dikkat çekicidir.

Çizelge 2. Manda yetiştiriciliğinin yetiştirici gözüyle sorunları

\begin{tabular}{|c|c|c|c|}
\hline \multirow{2}{*}{ Sorular } & \multirow{2}{*}{ Parametreler } & \multicolumn{2}{|c|}{ Bingöl İli Toplam } \\
\hline & & $\mathbf{n}$ & $\%$ \\
\hline \multirow{2}{*}{ Manda yetiştiriciliği Memnuniyeti } & Evet & 47 & 97.9 \\
\hline & Hayır & 1 & 2.1 \\
\hline \multirow{2}{*}{$\begin{array}{l}\text { Çocuklarınıza manda yetiştiriciliğini tavsiye } \\
\text { eder misiniz? }\end{array}$} & Evet & 40 & 80.0 \\
\hline & Hayır & 10 & 20.0 \\
\hline \multirow{5}{*}{$\begin{array}{l}\text { Manda yetiştiriciliğini bıraksanız ne iş } \\
\text { yaparsınız? }\end{array}$} & Hayvancilık & 9 & 22.5 \\
\hline & Çiftçilik & 18 & 45.0 \\
\hline & Sığır yetiştiriciliği-Besicilik & 7 & 17.5 \\
\hline & Başka iş yapmam-Bırakmam & 5 & 12.5 \\
\hline & Bitki üretimi & 1 & 2.5 \\
\hline \multirow{9}{*}{$\begin{array}{l}\text { Manda yetiştiriciliğinin sorunlarının } \\
\text { giderilmesi için yetkililerden en önemli } \\
\text { beklentiniz }\end{array}$} & Beklentim yok & 7 & 13.7 \\
\hline & Hayvancılıkla ilgili eğitim verilsin & 2 & 3.9 \\
\hline & Damızlık hayvan verilsin & 17 & 33.3 \\
\hline & Kredi verilsin & 6 & 11.8 \\
\hline & Veteriner hekim hizmetleri arttırılsın & 5 & 9.8 \\
\hline & Ürünlerin pazarlama imkânları arttırılsın & 8 & 15.7 \\
\hline & Mera/Otlak sorunu çözülsün & 4 & 7.8 \\
\hline & Destekleme az & 1 & 2.0 \\
\hline & Yem desteği & 1 & 2.0 \\
\hline \multirow{5}{*}{$\begin{array}{l}\text { İşletmenizde en çok para harcadığınız } \\
\text { uygulama }\end{array}$} & Hayvan hastalıkları/Sağlık hizmetleri & 3 & 5.9 \\
\hline & Yem alımı & 48 & 94.1 \\
\hline & Damızlık alımı & - & - \\
\hline & İşçi maliyeti & - & - \\
\hline & Barınak giderleri & - & - \\
\hline \multirow{2}{*}{$\begin{array}{l}\text { Manda yetiştiriciliği karlı hale getirilebilir } \\
\text { mi? }\end{array}$} & Evet & 47 & 95.9 \\
\hline & Hayır & 2 & 4.1 \\
\hline
\end{tabular}




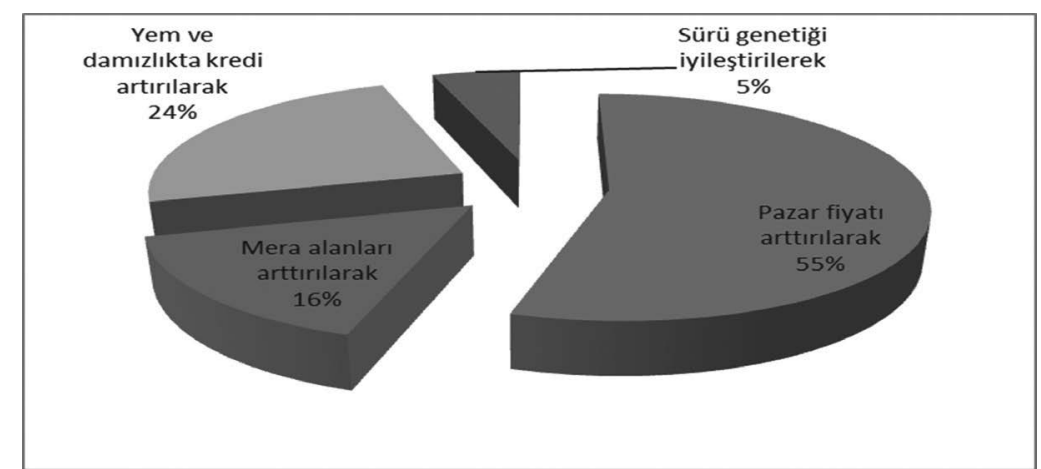

Şekil 4. Manda yetiştiriciliğinin karlı hale getirilebilmesi için yetiştirici önerileri

"Sı ğırlarla karşılaştırdığınızda manda yetiştiriciliğinde yaşadığınız farklılıklar nelerdir?" sorusuna katılımciların \%52.4'ü “Manda sütü ve süt ürünleri daha kaliteli ve lezzetli", \%17.1'i "Mandalar huysuz ve hırçın, bakımı daha zor", \%14.6's1 "Eti, sığır etine göre daha kaliteli ve lezzetli" olduğunu ifade etmişlerdir (Şekil 5). İneklere göre mandalar daha az süt üretir. Ancak manda sütünün tadı ve besin değeri kendine hastır. İnek sütüne göre yoğun kıvamlı bir süt olup, 2 kat yağ (\%8-11) ve daha az su içerir. A vitamini açısından zengin olmasından dolayı sütün rengi beyazdır. C vitamini ve Laktoz açısından da zengindir. Protein değeri ve mineral madde oranı yüksek olup, kolesterol miktarı ise inek sütüne göre düşüktür (Akbulut ve Yazıcı 2011; Çetinkaya ve ark. 2011; Kandır 2014a). Yetiştiriciler tarafindan zorluk olarak belirtilen huysuz ve hırçın olma hali, literatür bilgilerinde özellikle merada veya ahırda, alışkın olduğu bakıcılara sevk ve idarede güçlük çıkarmadığı, bakıcılarına karşı itaatkâr oldukları, alışık oldukları bakıcılarca sağıldıkları sürece ve sağım esnasında rahatsız edilmedikleri takdirde elle veya makine ile kolay bir şekilde sağılabilecekleri şeklinde açıklanmaktadır (Hekimoğlu ve Altındeğer 2009; Kandır 2014a).
Manda eti, kimyasal içeriği, besin değeri ve tadı bakımından sığır etine benzemekle birlikte sığır etine göre biraz daha koyu kırmızıdır. Manda karkasının yağları beyaz, sığırın ise sarımsı renktedir. Daha düşük kolesterol, yağ ve kalori değerleri ile inek etine göre üstünlük sağlamaktadır. Mandalar eti için beslenip, küçük yaşta kesilirler ise, sığır etinden daha lezzetli bir et elde edilir. Manda eti, bakır, fosfor ve demir açısından da zengindir. Manda eti özellikle sucuk hamuruna \%10-30 oranında katılması ürünün lezzet, aroma ve rengini olumlu yönde etkilerken, sucuğun fermantasyon süresini de kısalttığ (Hekimoğlu ve Altındeğer 2009; Çetinkaya ve ark. 2011; Kandır 2014a). Katılımcıların özellikle evlerinin günlük ihtiyacı için manda yetiştiriciliği yaptığ 1 nı beyan etmeleri ve sığır ürünlerine karşı üstün ve ayırıcı özelliklere sahip, manda ürünlerinin kalite ve lezzetini vurgulamaları, manda yetiştiriciliğinin üreticiler için bir vazgeçilmezliğini ortaya koymaktadır. Soysal ve ark. 2005, yükselen bir trend olarak tüketici talebi ile manda et ve süt üretimi popülaritesi $\operatorname{arttığ} 1$ için yetiştirici nezdinde daha fazla önem kazandığg bildirilmiştir.

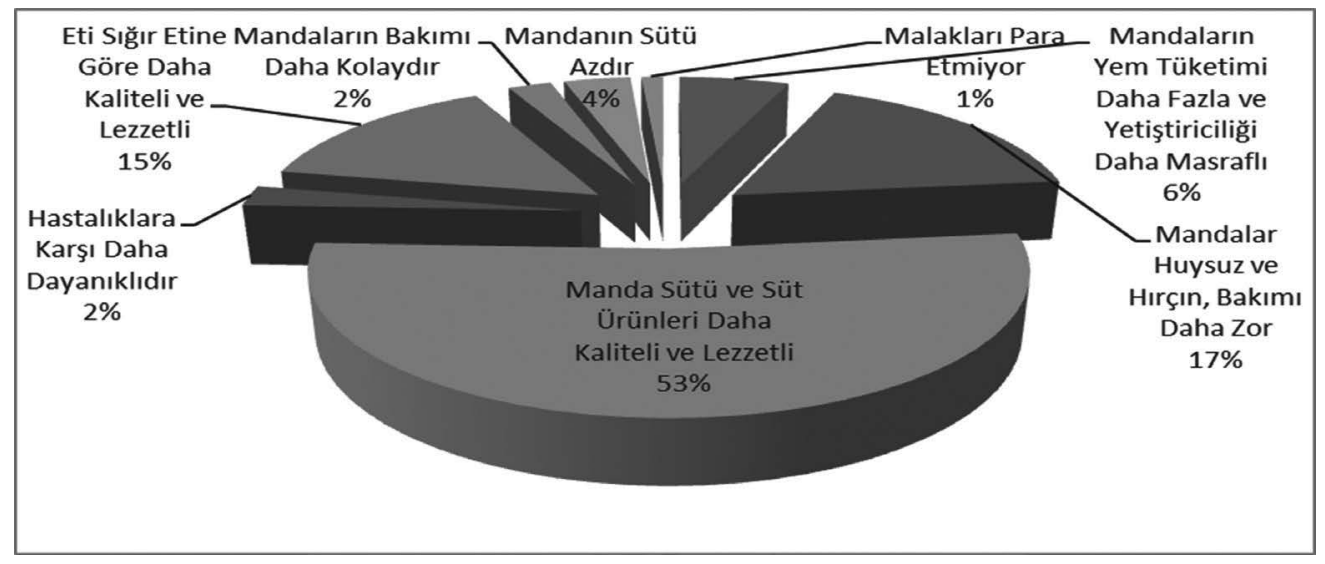

Şekil 5. Yetiştirici gözüyle manda ve sığır yetiştiriciliğinin karşılaştırılması 


\section{SONUÇ}

Bugün dünyanın pek çok bölgesinde niteliksiz kaba yemleri sığırlara göre daha etkin şekilde değerlendirebilmesi, her türlü iklim koşullarına kolayca uyabilmesi, organik hayvancılığa temel oluşturması gibi (Atasever ve Erdem 2008; Çiçek ve Tandoğan 2009; Şahin ve ark 2013) önemli avantajlara sahip olan mandanın gerek yetiştirici alışkanlığı gerekse ürünlerinin kalitesi sebebiyle yetiştiriciler arasında vazgeçilmez olarak görülmektedir. Ancak manda yetiştiricilerinin hayvancılık ve yan kollarını oluşturan alanlarda çalışmayı devam ettirmeyi istediklerini ancak bu devamlılığın sağlanabilmesi adına teşvik ve destek beklentisi içerisinde oldukları söylenebilir. Manda yetiştiriciliğinin sahip olduğu potansiyel ile yetiştiricilerin organik üretime istekli olmaları birlikte değerlendirildiğinde manda yetiştiriciliğine yeniden cazibe kazandırılabileceği düşünülmektedir. Özellikle katılımcıların, manda yetiştiriciliğinin karlı hale getirilebileceği inancına sahip olmaları ve bu durum ise pazar fiyatlarının artırılması yoluyla sağlanabileceği önerisini sunmaları, yetiştiricilerin bu konuda teşvik edilmesi gerekliliğini ve ayrıca üretimlerinin ek primler ile desteklemelerinin önemini ortaya koymaktadır. Organik ürünün pazar fiyatının geleneksel ürünlere göre yaklaşık \%25-50 arasında yüksek olması üretici açısından teşvik edici niteliktedir (Çiçek ve Tandoğan 2009). Ancak organik üretim ile mevcut ekonomik koşullar ve tüketici gelir düzeyleri gibi unsurlar birlikte değerlendirildiğinde hayvancılık sorunlarını çözmeye yönelik bir yöntem olarak düşünülmemelidir (Çiçek ve Tandoğan 2009).

Sonuç olarak, katılımcıların tamamına yakınının manda yetiştiriciliğinden memnun olmaları, bu yetiştiriciliği çocuklarına tavsiye etmeleri, yetiştiriciliğin karlı hale getirilebileceği inancına sahip olmaları, organik üretime gönüllü ve manda ürünlerin önemi ve kalitesinin farkında oldukları tespit edilmiştir. Çalışma bulguları ile bölge olanakları birlikte değerlendirildiğinde, Bingöl ili özelinde manda yetiştiriciliğinin geliştirilebilmesi için yetiştiricilere organik yetiştiricilik imkanları kullanma yönünde teşvik edilmeleri ile organik ürünün pazar fiyatının geleneksel ürünlere göre yüksek olması üretici açısından manda yetiştiricilerinin sorunlarına karşılık yetkilerden beklentileri ve çözüm önerilerini karşılayacak bir gelişme olacağı düşünülmektedir.

\section{KAYNAKLAR}

Akbulut Ç, Yazıcı F, 2011. Bafra Kızılırmak Deltasında Elde Edilen Manda Sütlerinin Değerlendirilmesi ve Deltadaki Ekolojik Dengeyi Korumada Önemi. Samsun Sempozyumu, 13-16 Ekim 2011, Samsun.

Alpan O, Aksoy AR, 2012. Sığır Yetiştiriciliği ve Besiciliği. Kafkas Üniversitesi Veteriner Fakültesi Zootekni AD. 6. Bask1. ISBN 975-95445-0-4, KARS.

Anonim, 2013. Bingöl İli Tarımsal Yatırım Rehberi. T.C. Gıda Tarım ve Hayvancılık Bakanlığı Strateji Geliştirme Başkanlığı Tarımsal Yatırımcı Danışma Ofisi.

Atasever S, Erdem H, 2008. Manda Yetiştiriciliği ve Türkiye'deki Geleceği. OMÜ Zir. Fak. Dergisi,23(1):59-64.

Atasever M, Günlü A, Aydın E, Yıldız A, 2013. Doğu Anadolu Bölgesi'nde Hayvansal Üretimin Genel Değerlendirmesi ve Çözüm Önerileri. Atatürk Üniversitesi Vet. Bil. Derg., 8(2): 174-191.

Borghese A, Mazzi M, 2005. Buffalo population and strategies in the world. In, Borghese A (Ed): Buff alo Production and Research. 1st ed., pp. 1-39, Rome, Italy, 2005. htt p://www.fao.org/docrep/010/ ah847e/ah847e00.htm. Accessed: 26.03.2010.

Çakmak C, Karadavut U, Özdemir G, Sevinç N, 2010. Bingöl İlinde Organik Süt Üretim Olanaklarının Araştırılması. Türkiye I. Organik Hayvancılık Kongresi. 1-4 Temmuz, Kelkit.

Çetinkaya N, Genç B, Salman M, 2011. Samsun İli Manda Yetiştiriciliği. Samsun Sempozyumu, 13-16 Ekim 2011,Samsun.

Çiçek H, Tandoğan M, 2009. Organik Süt Sığırcıllğında Üretim Maliyetleri ve Karlılık Açısından Bir Değerlendirme. Kafkas Üniv Vet Fak Derg., 15(1):145-151.

Dellal G, Eliçin A, Tekel N, Dellal İ, 2002. GAP Bölgesinde Küçükbaș Hayvan Yetiștiriciliğinin Yapısal Özellikleri. Proje Raporu 2002-1, T.C. Tarım ve Köyişleri Bakanl1$\breve{g}_{1}$, Tarım Ekonomisi Araştırma Enstitüsü Yayınları No: 82, ISBN: 975-407-102-0. 82 S. ANKARA.

Hekimoğlu B, Altındeğer M, 2009. Samsun İlinde Manda Üretimi ve Manda Sütü Ürünleri Potansiyelinin Geleceği. Santim. 25:10-19.

İmik H, 2000. Anadolu Mandalarında Beslemenin Bazı Özellikleri Üzerine Etkisi. Türk Veteriner Hekimliği Dergisi. 12(1):18-26.

Kandır EH, 2014a. Manda Dünyasına Yolculuk. Ayrıntı $1(10): 24-28$.

Kandır EH, 2014b. Afyon Kocatepe Üniversitesinden Manda Yetiştiriciliğine Modern Bir Yaklaşım. Ayrıntı 2(12):3942.

Karadavut U, Çakmak C, Özdemir G, Sevinç N, 2010. Bingöl İli Hayvancılık İşletmelerinin Teknik ve Ekonomik Yapıları Üzerine Bir Araştırma. 3. Bingöl Sempozyumu, 17-19 Eylül, Bingöl.

Küçükkebabçı M, Aslan S, 2002. Evcil Dişi Mandaların Üreme Özellikleri. Lalahan Hay. Araşt. Enst. Derg. 42(2): 55-63. 
Murat H, Sakarya E,. 2012. Orta Anadolu bölgesi damızlık sığır yetiştirici birliklerine bağlı süt sığırcıllk işletmelerinin ekonomik analizi. Vet Hekim Der Derg, 83(1): $5-14$.

Özçelik A, Şahinli MA, 2011. Konya İlinde Koyunculuk Faaliyetine Yer Veren Tarım İşletmelerinin Ekonomik Analizi Ve Koyunculuk Faaliyetinde Etkili Olan Unsurların Saptanması. Ankara Üniv., Fen Bilimleri Enst., Doktora Tezi, ANKARA.

Özdemir G, Çakmak C, Karadavut U, Sevinç N, 2010. Bingöl İlinde Organik Hayvansal Ürün Yetiştirme Potansiyellerinin Araştırılması. Türkiye IV. Organik Tarım Sempozyumu, 28 Haziran - 1 Temmuz, Erzurum.

Sarıözkan S, 2011. Türkiye'de Manda Yetiştiriciliği'nin Önemi. Kafkas Üniv Vet Fak Derg, 17 (1): 163-166.

Soysal Mİ, Tuna YT, Gürcan EK,. 2005. An Investigation on the Water Buffalo Breeding in Danamandira Village of Silivri District of Istanbul Province of Turkey. Tekirdağ Ziraat Fakültesi Dergisi, 2(1):73-78.
Şahin A, Ulutaş Z, Yıldırım A, 2013. Türkiye ve Dünya'da Manda Yetiştiriciliği. Gaziosmanpaşa Bilimsel Araştırma Dergisi. 8, 65-70.

Şeker İ, Tasalı H, Güler H, 2012. Muş İlinde Sığır Yetiştiriciliği Yapılan İşletmelerin Yapısal Özellikleri. F.Ü. Sağ. Bil. Vet. Derg., 26 (1): 09 - 16. http://www.fusabil.org

Şekerden Ö, Borghese A, Köroğlu M, Uras H, Güzey ZY, 2005. Anadolu Mandalarında Sun'i Tohumlama Çalışmaları ve PRID (Progesterone Releasing Intravaginal Device) Uygulamanın Döl Tutma Oranı Üzerine Etkisi. Tarım Bilimleri Dergisi, 11(2):126-128.

TÜİK 2015. Türkiye İstatistik Kurumu. www.tuik.gov.tr. Ankara. Erişim tarihi: 28.04.2015.

Türkyılmaz MK, Nazlıgül A, 2002. Türkiye Ekonomisinde Hayvancılığın Rolü ve Sorunları. Kafkas Üniv Vet Fak Derg, 8(2):177-181. 